\title{
Phenotypic plasticity in pre-feeding larvae of sea urchins, Mesocentrotus nudus and Strongylocentrotus intermedius
}

\author{
Alexander V. Kalachev¹, Olga V. Yurchenko', Vladimir G. Osten² \\ ${ }^{1}$ National Scientific Center of Marine Biology, Far Eastern Branch of the Russian Academy of \\ Sciences, 17 Palchevskogo str., Vladivostok, 690041, Russia.E-mail: akalachev@imb.dvo.ru \\ ${ }^{2}$ Far Eastern Federal University, Vladivostok, 690090, Russia
}

ABSTRACT: Experimental studies showed that in echinoids egg size of a species affects magnitude of phenotypic plasticity in larvae of the species. Here we tested whether any difference in magnitude of plasticity exists in pre-feeding larvae of two sea urchins, Mesocentrotus nudus (A. Agassiz, 1864) and Strongylocentrotus intermedius (A. Agassiz, 1864). These species are closely related by their phylogenetic position, have overlapping ranges, and differ by size of their eggs. Our results indicate that by the end of pre-feeding development ( $4 \mathrm{~d}$ after fertilization) the larvae from high algae treatment ( 8000 cells $1 \mathrm{ml}^{-1}$ ) had shorter post-oral arms as compared to their siblings of the same age from no algae treatment ( 0 cells $\left.1 \mathrm{ml}^{-1}\right)$. In spite the egg volume of $M$. nudus was approximately 2-times bigger than that in $S$. intermedius, relative difference in post-oral arms length in no algae and high algae conditions in $S$. intermedius was approximately 1.5 times larger. Our results support the assumption that the degree of phenotypic plasticity in the larvae, developing from smaller eggs with lower maternal investment, is higher than in the larvae, developing from bigger eggs. We propose that pre-feeding larvae of $S$. intermedius are more phenotypically plastic than the larvae of $M$. nudus.

How to cite this article: Kalachev A.V., Yurchenko O.V., Osten V.G. 2018. Phenotypic plasticity in pre-feeding larvae of sea urchins, Mesocentrotus nudus and Strongylocentrotus intermedius // Invert. Zool. Vol.15. No.4. P.420-433. doi: 10.15298/invertzool.15.4.09

KEY WORDS: Sea urchins, larvae, development, phenotypic plasticity, maternal investment.

\section{Фенотипическая пластичность у еще непитающихся личинок морских ежей Mesocentrotus nudus и Strongylocentrotus intermedius}

\author{
А.В. Калачев¹, О.В. Юрченко', В.Г. Остен²
}

\begin{abstract}
${ }^{1}$ Национальный научный иентр морской биологии Дальневосточного отделения Российской академии наук, Пальчевского 17, Владивосток, 690041, Россия.E-mail: akalachev@imb.dvo.ru ²Дальневосточный федеральный университет, Владивосток, 690090, Россия
\end{abstract}

РЕЗЮМЕ: Из экспериментальных исследований известно, что у морских ежей размер яиц влияет на степень проявления фенотипической пластичности. В данной работе рассматривается вопрос: существует ли разница в степени выраженности фенотипической пластичности у морских ежей Mesocentrotus nudus (A. Agassiz, 
1864) и Strongylocentrotus intermedius (A. Agassiz, 1864). Данные виды близки филогенетически, имеют близкие ареалы и различаются размером яиц. Исследование показало, что к 4-м суткам после оплодотворения у личинок обоих видов, развивавшихся при высокой концентрации микроводорослей (8 000 клеток/мл) длина посторальных рук была статистически достоверно меньше таковой у личинок, развивавшихся в отсутствии микроводорослей (0 клеток/мл). Несмотря на то, что объем яиц у $M$. nudus приблизительно в 2 раза больше чем у S. intermedius, относительное изменение длины посторальных рук между контрольной (0 клеток/мл) и экспериментальной (8 000 клеток/мл) группами у S. intermedius было в полтора раза больше, чем у M. nudus. Наши результаты согласуются с предположением, что фенотипическая пластичность более выражена у личинок морских ежей, развивающихся из яиц меньшего размера, с меньшим материнским вкладом в потомство. Мы полагаем, что 4-дневные личинки S. intermedius более пластичны в росте посторальных рук, чем таковые $M$. nudus.

Как цитировать эту статью: Kalachev A.V., Yurchenko O.V., Osten V.G. 2018. Phenotypic plasticity in pre-feeding larvae of sea urchins, Mesocentrotus nudus and Strongylocentrotus intermedius // Invert. Zool. Vol.15. No.4. P.420-433. doi: 10.15298/invertzool.15.4.09

КЛЮЧЕВЫЕ СЛОВА: морские ежи, личиночное развитие, фенотипическая пластичность, материнский вклад.

\section{Introduction}

Experimental studies showed that planktotrophic larvae of many echinoderms are phenotypically plastic and can alter their morphology in response to the amount of food in the environment. For example, bipinnariae larvae of a forcipulate sea star, Pisaster ochraceus, when develop in food-limited conditions, are shorter than those larvae of the same age, who developed when food is abundant (George, 1999). Phenotypic plasticity was also observed in larvae of ophiuroids of the genus Macrophiotrix: the larvae grow longer postero-lateral arms when food is scarce (Podolsky, McAlister, 2005). However, much more data on phenotypic plasticity are available for echinoids — to date larvae of nearly twenty species of sea urchins and sand dollars were tested for phenotypic plasticity (McAlister, Miner, 2018). The list of the tested species includes representatives of the orders Camarodonta (Bertram, Strathmann, 1998; Meidel et al., 1999; Miner, Vonesh, 2004; Sewell et al., 2004), Cidaroida (McAlister, 2008), Clypeasteroida (Boidron-Métairon, 1988; McAlister, 2008; Reizel, Heyland, 2007; Rendleman et al., 2018), and Diadematoida
(Eckert, 1998; McAlister, 2008; Soars et al., 2009). These studies showed that larvae of many echinoids differentially grow their postoral arms in response to various concentrations of food. The larvae who developed in foodlimited environment grow longer post-oral arms at the onset of feeding as compared their siblings of the same age who developed in foodabundant environment (see for review Soars et al., 2009; McAlister, Miner, 2018). As a result, larvae from food-limited environment bear longer ciliary bands which allow them to capture food particles more efficiently (Hart, Strathmann, 1994). Many researchers consider this change in the length of post-oral arms as an offensive response of the larvae directed towards to improve food acquisition (Hart, Strathmann, 1994; Byrne et al., 2008a; Soars et al., 2009). This is especially important for the species inhabiting regions where food resources are limited or can change dramatically (Hart, Strathmann, 1994; McAlister, 2008). It worth noting that to date, plastic growth of post-oral arms was found mainly in temperate species of echinoids, while in the larvae of tropical and subtropical ones phenotypic plasticity is less pronounced or even absent (McAlister, 2008; Soars et al., 2009). 
A few factors were suggested to affect occurrence and magnitude of plasticity in arms growth in echinoderm larvae, such as egg size of the species, the latitude where the species lives and phylogeny of the species (Reizel, Heyland 2007; Soars et al., 2009; Padilla-Gaminõ et al., 2013; McAlister, Miner, 2018). Of these factors eggs size probably plays the most important role since it is considered as a rough proxy for energy content within an egg and, hence, may reflect maternal investment into their offspring (Herrera et al., 1996; Kasyanov, 2001; Allen, Pernet, 2007; Byrne et al., 2008b). According to McAlister \& Miner (2018), there are two hypotheses which connect egg size and magnitude of phenotypic plasticity. In one hand, larvae developing from smaller eggs are more plastic since they are more dependent on exogenous resources and the larvae expressing a higher degree of phenotypic plasticity gather food from the environment more efficiently. On the other hand, the larvae developing from bigger eggs are provided with more endogenous resources and, hence, are able to express a greater degree of phenotypic plasticity when exogenous food resources are scarce. Experimental data support both "smaller eggs" (Reizel, Heyland, 2007) and "larger eggs" hypotheses (McAlister, 2007). McAlister \& Miner (2018) concluded "that the relationship between plasticity and egg size is a combination of both hypotheses, and reflects a nonlinear negative relationship between these variables for feeding larvae." Although there is a general agreement on how egg size is related to the expression and the magnitude of phenotypic plasticity in echinoid larvae, more empirical data are required to better understand this relationship.

This study aims to test whether any plasticity in post-oral arms growth in pre-feeding larvae of two echinoid species, Mesocentrotus nudus (A. Agassiz, 1864) and Strongylocentrotus intermedius (A. Agassiz, 1864), exists, and how big is the difference, if any, in the magnitude of plasticity in arms growth between the species. These species were selected because they are closely related by their phylogenetic position, have overlapping ranges, and differ by size of their eggs.

\section{Material and methods}

\section{Animals collection}

Mature males and females of M. nudus (test diameters were $50.2 \pm 3.35^{1} \mathrm{~mm}$ ) and $S$. intermedius (test diameters were $50.6 \pm 1.52 \mathrm{~mm}$ ) were collected from the same locality in the vicinity of Vladivostok (Ussuri Bay, Sea of Japan, Russia) during their natural spawning seasons in June ( $S$. intermedius) and July ( $M$. nudus) of 2017 and 2018.

\section{Larvae rearing}

For each species five independent experiments were carried out. In each experiment gametes from one male and one female were used for crossing, so the larvae were full siblings. Mature animals were induced to spawn by injecting of $1 \mathrm{ml}$ of $0.5 \mathrm{M} \mathrm{KCl}$ into the coelomic cavity. For each female, 50 fresh unfertilized eggs were photographed under a Zeiss AxioImager Z.2 microscope, equipped with a digital camera Axio Cam Hrc. Egg diameters were measured using ImageJ image analysing software, version 1.52g (Schindelin et al., 2012; Schneider et al., 2012). Assuming the final shape of the eggs as a sphere, their volumes were calculated using the sphere volume equation $\left(\mathrm{V}=4 / 3 \pi \mathrm{r}^{3}\right)$.

Larvae rearing were done according to recommendations of Kashenko (2010). Embryos at blastula or early gastrula stage (24 hours postfertilization) were partitioned at a density of 1 larva $1 \mathrm{ml}^{-1}$ into 51 glass beakers filled with filtered and UV sterilized sea water (FSW). The beakers were aerated and maintained at $20^{\circ} \mathrm{C}$ with $13 / 11$ h day/night cycle. Each experiment consisted of 6 beakers randomly assigned into following treatments ( 2 beakers per treatment): 0 algal cells $1 \mathrm{ml}^{-1}$ (NA), 800 algal cells $1 \mathrm{ml}^{-1}$ (LA), and 8000 algal cells $1 \mathrm{ml}^{-1}$ (HA). The larvae from LA and HA treatments were provided with the algae, Chaetoceros muelleri Lem-

\footnotetext{
${ }^{1}$ Data on test diameters presented as mean \pm one standard deviation
} 
mermann, 1898, on days 1 and 3 of the experiment. To remove culture medium appropriate volumes of the algae culture were centrifuged, the supernatant was carefully removed by a pipette, and the pellet was resuspended in FSW. All experiments were terminated at day 5 of larval development.

\section{Larvae morphometrics}

By the end of pre-feeding period, on day 4 of development, 20 to 30 plutei from each beaker were collected and preserved by a few drops of $4 \%$ paraformaldehyde. Next, the larvae were immediately mounted on microscope slides, covered with cover slips, and photographed under a Zeiss AxioImager Z.2 microscope, equipped with EC Pan-Neofluar 20×/0.5 objective lens and a digital camera Axio Cam Hrc. Three larval traits (Fig. 1), namely, body rod length (BR), post-oral arms length (PO), and midline body length (MBL) were measured for 5 larvae per beaker. In total, 50 larvae were measured per treatment (10 larvae per experiment).

A modification of McEdward's $(1984,1985)$ method was used for measuring the larvae. For each larva a series of optical sections (Z-stack) in ZVI file format was captured. Next, each appropriately scaled Z-stack was imported into Image J image analysing software, where $\mathrm{X}$ and $Y$ coordinates (in micrometers) and optical section position in the Z-stack of start and end points of a structure of interest were collected (Fig. 2). The length of the structure of interest was calculated using straight line distance equation

$$
\mathrm{L}=\sqrt{\left(x_{2}-x_{1}\right)^{2}+\left(y_{2}-y_{1}\right)^{2}+\left(\left(z_{2}-z_{1}\right) \times t\right)^{2}}
$$

where $L$ is the length of the structure of interest; $x_{1}, y_{1}$ and $x_{2}, y_{2}$ are coordinates of start and end points of the structure of interest, respectively; $z_{1}$ and $z_{2}$ are slice positions in the Z-stack, and $t$ is the thickness of the optical section (in micrometers).

\section{Statistical analysis}

All statistical analyses were performed using the R system for statistical computing, ver-

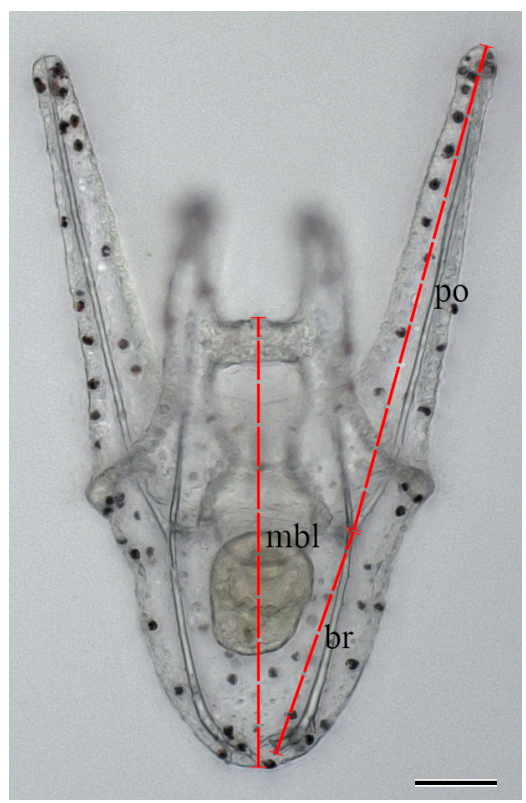

Fig. 1. Mesocentrotus nudus. Four-armed pluteus (4 days after fertilization) illustrating the body rod (br), midline of the body ( $\mathrm{mbl}$ ), and post-oral arms (po). Scale bar $50 \mu \mathrm{m}$.

Рис. 1. Mesocentrotus nudus. Скелетные иглы (br), средняя линия тела (mbl) и посторальные руки (ро) у четырехрукого плутеуса (4-е сутки после оплодотворения). Масштаб $50 \mu \mathrm{m}$.

sion 3.5.1 (R Core Team, 2018). Prior to analysis, datasets on egg diameters and larvae for each species were tested for normality with Shapiro-Wilk test and for homogeneity of variance with Levene's test. For statistical analysis of egg diameters 5 egg measurements per female were randomly sampled from the initial dataset. Within species comparisons of egg diameters were done using one-way analysis of variance (one-way ANOVA) and between species comparison of egg diameters was done by two-sample $t$-test.

Effect of algae concentration on plutei growth were analyzed by nested analysis of variance (nested ANOVA) with "Treatment" as a fixed factor and "Experiment" as a random factor nested within "Treatment". Multiple comparisons of egg diameters between females and plutei characters between experimental treat- 

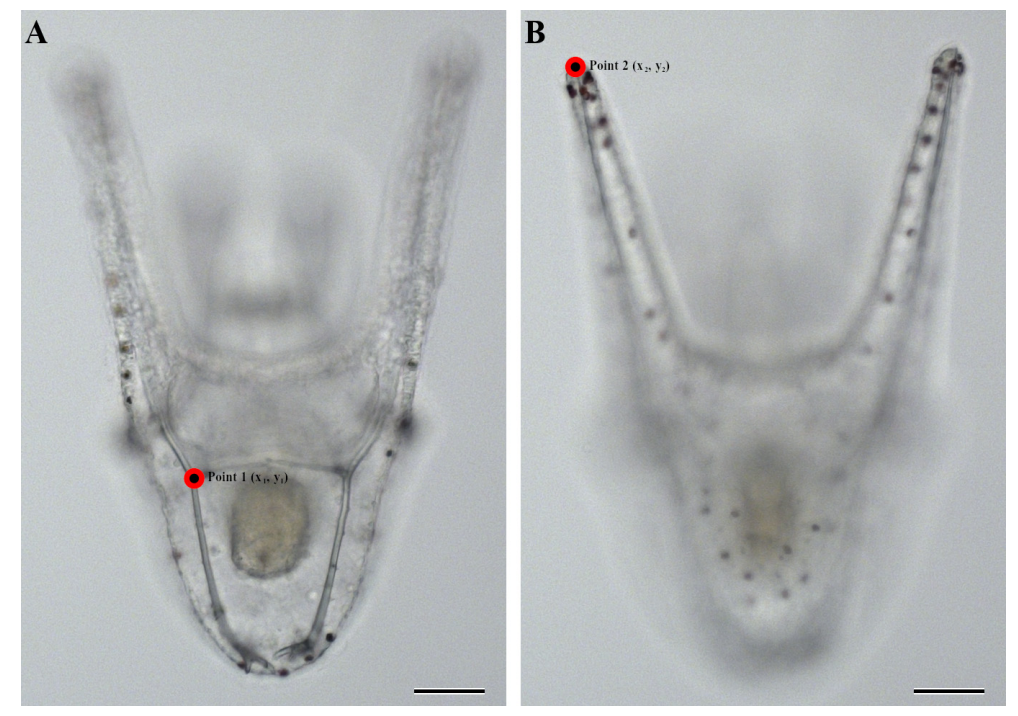

Fig. 2. Mesocentrotus nudus. Two optical section of a four-armed pluteus (4 days after fertilization), illustrating that left post-oral arm starts (A) and ends (B) at different planes of focus. The Point 1 marks where the arm begins and the Point 2 is where the arm ends. $x_{1}, y_{1}$ and $x_{2}, y_{2}$ are horizontal coordinates of Point 1 and Point 2, respectively. Scale bar $50 \mu \mathrm{m}$.

Рис. 2. Mesocentrotus nudus. Два оптических среза четырехрукого плутеуса (4-е сутки после оплодотворения), демонстрирующие, что левая посторальная рука начинается (А) и заканчивается (В) в различных фокальных плоскостях. Точка 1 указывает начало руки и точка 2 - конец руки; $x_{1}, y_{1}$ и $x_{2}$, $y_{2}$ координаты точек 1 и 2 соответственно. Масштаб $50 \mu \mathrm{m}$.

ments were done using the Tukey's honest significance (Tukey's HSD) test provided by R add-on package "multcomp", version 1.3.3 (Hothorn et al., 2008). Pairwise comparisons for between species difference in the absolute and relative lengths of post-oral arms between experimental treatments were done using R addon package "emmeans", version 1.2.3 (Lenth, 2018). Differences in all analyses were considered as statistically significant at the level of $p<$ $5 \times 10^{-2}$.

\section{Results}

\section{Eggs}

We found that egg diameters in both species differed between females (Table 1). In absolute values, these differences were up to 10 and $15 \%$ in $M$. nudus and S. intermedius, respectively. Statistical analysis revealed that egg diameters between females in $M$. nudus were statistically significantly different (one-way ANOVA: $F(4$, $20)=96.58, p=8.77 \times 10^{-13}$ ). Tukey's HSD test revealed that in $M$. nudus egg diameters in females from experiments 1 and 5 were statistically significantly different from one another, as well as from those in the experiments 2,3 , and $4\left(p<1 \times 10^{-3}\right)$. At the same time, no statistically significant difference in egg diameters between females in the experiments 2, 3, and 4 was found. Similarly, the difference in egg diameters between females in $S$. intermedius was statistically significant (one-way ANOVA: $F(4$, $\left.20)=176.98, p=2.63 \times 10^{-15}\right)$. Tukey's HSD test showed that in $S$. intermedius the difference in mean egg diameters was statistically nonsignificant between females from the experiments 1 and 2, while all other pairwise comparisons were statistically significant $\left(p<5 \times 10^{-2}\right)$.

Between species comparison showed that egg diameters of $M$. nudus and $S$. intermedius were statistically significantly different ( $t$-test: 
Table 1. Descriptive statistics of eggs size in the studied species of sea urchins. The data presented as mean \pm one standard deviation. The sample size in each experiment is 50 .

Таблица 1. Описательная статистика размеров яиц у исследованных видов морских ежей. Данные представлены в виде средних \pm одно стандартное отклонение. Размер выборки - 50 яиц в каждом эксперименте.

\begin{tabular}{|cccc|}
\hline Species & Experiment & Egg diameter $(\boldsymbol{\mu m})$ & Egg volume (nl) \\
\hline & 1 & $120.23 \pm 2.63$ & $0.91 \pm 0.06$ \\
M. nudus & 2 & $108.00 \pm 4.37$ & $0.66 \pm 0.08$ \\
& 3 & $107.17 \pm 3.21$ & $0.65 \pm 0.06$ \\
& 4 & $107.69 \pm 3.14$ & $0.66 \pm 0.06$ \\
& 5 & $113.87 \pm 2.46$ & $0.78 \pm 0.05$ \\
\hline \multirow{3}{*}{ intermedius } & 1 & $92.06 \pm 1.81$ & $0.41 \pm 0.03$ \\
& 2 & $91.02 \pm 2.51$ & $0.39 \pm 0.03$ \\
& 3 & $101.41 \pm 1.37$ & $0.54 \pm 0.02$ \\
& 5 & $86.80 \pm 1.81$ & $0.34 \pm 0.02$ \\
& 5 & $89.54 \pm 2.78$ & $0.38 \pm 0.04$ \\
\hline
\end{tabular}

$\left.\mathrm{t}(48)=13.69, p=2.2 \times 10^{-16}\right)$. In absolute values mean egg diameters of $M$. nudus were approximately 17\% larger than those of S. intermedius, while the difference in egg volumes was approximately 2-fold (Table 1).

\section{Larvae morphometrics}

\section{Mesocentrotus nudus}

On day 4 of development larvae of $M$. nudus in all experimental treatments reached fourarmed pluteus stage; no delay or any disturbance in embryonic development of the larvae from all experimental treatments was observed. It worth noting, that no algae were observed in the stomachs of larvae from LA and HA treatments. Statistical analysis revealed no statistically significant effect of algae on the mean length of body rods (nested ANOVA: $F(2,143)=$ $\left.1.81, p=1.68 \times 10^{-1}\right)$. The length of body rods in the larvae from all experimental treatments was approximately the same and did not exceed $2-2.5 \%$ (Fig. 3A; Table 2). The mean length of post-oral arms was found to be statistically significantly different (nested ANOVA: $F(2$, $\left.143)=28.73, p=3.02 \times 10^{-11}\right)$. Tukey's HSD test showed statistically significant difference between all treatments: NA-HA $\left(p<1 \times 10^{-4}\right)$, NA-LA $\left(p<1 \times 10^{-4}\right)$ and HA-LA $(p=2.2 \times$ $\left.10^{-3}\right)$. In absolute values, the larvae from NA experimental treatment had approximately 5 and $9 \%$ longer post-oral arms as compared to those from LA and HA experimental treatments, respectively (Fig. 3B; Table 2). The difference in mean post-oral arms length between larvae from LA and HA experimental treatments was approximately $4 \%$.

No statistically significant difference in the midline body length was found between treatments (nested ANOVA: $F(2,143)=0.46, p=$ $\left.6.3 \times 10^{-1}\right)$. In absolute values, the difference in midline body length did not exceed $0.5 \%$ in any of pairwise comparisons between the treatments (Fig. 3C; Table 2). Finally, statistical analysis showed that post-oral arms to midline body length ratio statistically significantly differed between the larvae (nested ANOVA: $F(2,143)$ $\left.=31.17, p=5.3 \times 10^{-12}\right)$. Tukey's HSD test showed that all pairwise comparisons were statistically significant: NA-HA $\left(p<1 \times 10^{-4}\right)$, NA-LA $\left(p<1 \times 10^{-4}\right)$, and LA-HA $(p=3.7 \times$ $\left.10^{-4}\right)$. In absolute values the mean difference in the PO:MBL ratios were as follows: NA:HA 9\%, NA:LA $-5 \%$, and HA:LA - 4\% (Fig. 3D; Table 2).

\section{Strongylocentrotus intermedius}

On day 4 of embryonic development the larvae in all experimental treatments were at four-armed pluteus stage. As for the larvae of $M$. nudus, no delay or any disturbance in embryonic development was found; no algae were observed in stomachs. However, significant effect of algae concentration during embryonic devel- 


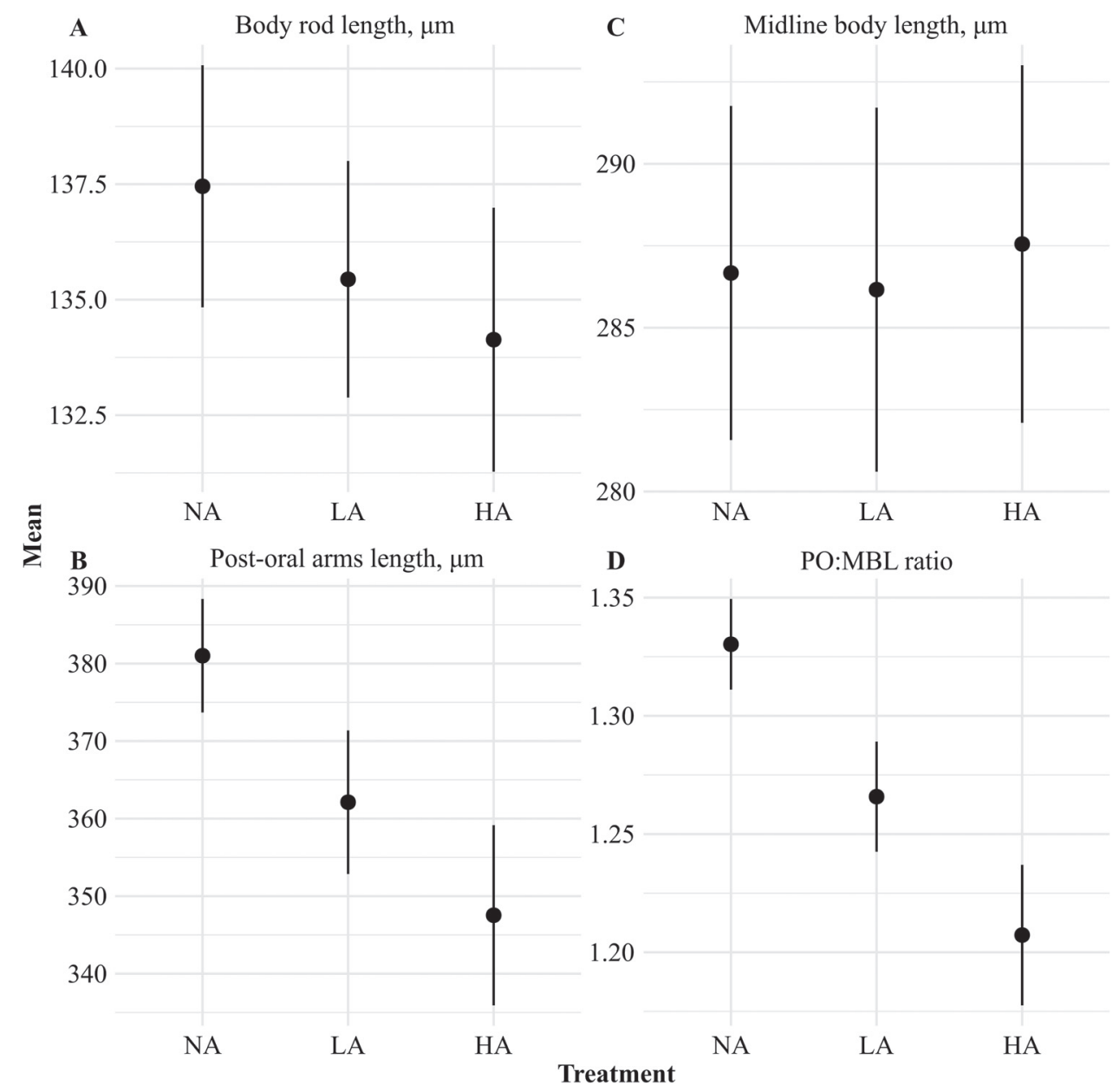

Fig. 3. Mesocentrotus nudus. Whisker plots of the pooled datasets for lengths of body rods (A), post-oral arms (B), midline body lengths (C), and PO:MBL ratios in $4 \mathrm{~d}$ old larvae from different experimental treatments. Black dots are means and whiskers around mean represent $95 \%$ confidence interval of the mean. Рис. 3. Mesocentrotus nudus. Средние значения (точка) и 95\% доверительные интервалы («усы») данных по длине скелетных игл (A), посторальных рук (B), средней линии тела (C) и отношения длины посторальных рук к длине средней линии тела (D) четырехдневных личинок из разных экспериментальных групп.

opment on morphometrics of pre-feeding larvae was observed. First, the effect of algae concentration on the mean body rod length was found to be statistically significant (nested ANOVA: $\left.F(2,143)=3.24, p=4.22 \times 10^{-2}\right)$. Tukey's HSD test showed that mean length of the body rods in the larvae from HA experimental treatment was statistically different from those in LA ( $p=3.5$ $\times 10^{-2}$ ) experimental treatment. No statistically significant difference in the mean body rod lengths was found between NA and LA $(p=7.2$ $\left.\times 10^{-1}\right)$, as well as between NA and HA $(p=2.0$ $\times 10^{-1}$ ) treatments. In absolute values, the body rods in the larvae from HA experimental treatment were approximately $2 \%$ shorter, than those in the larvae from LA experimental treatment, while other differences did not exceed $1.5 \%$ (Fig. 4A; Table 2). Statistically significant dif- 


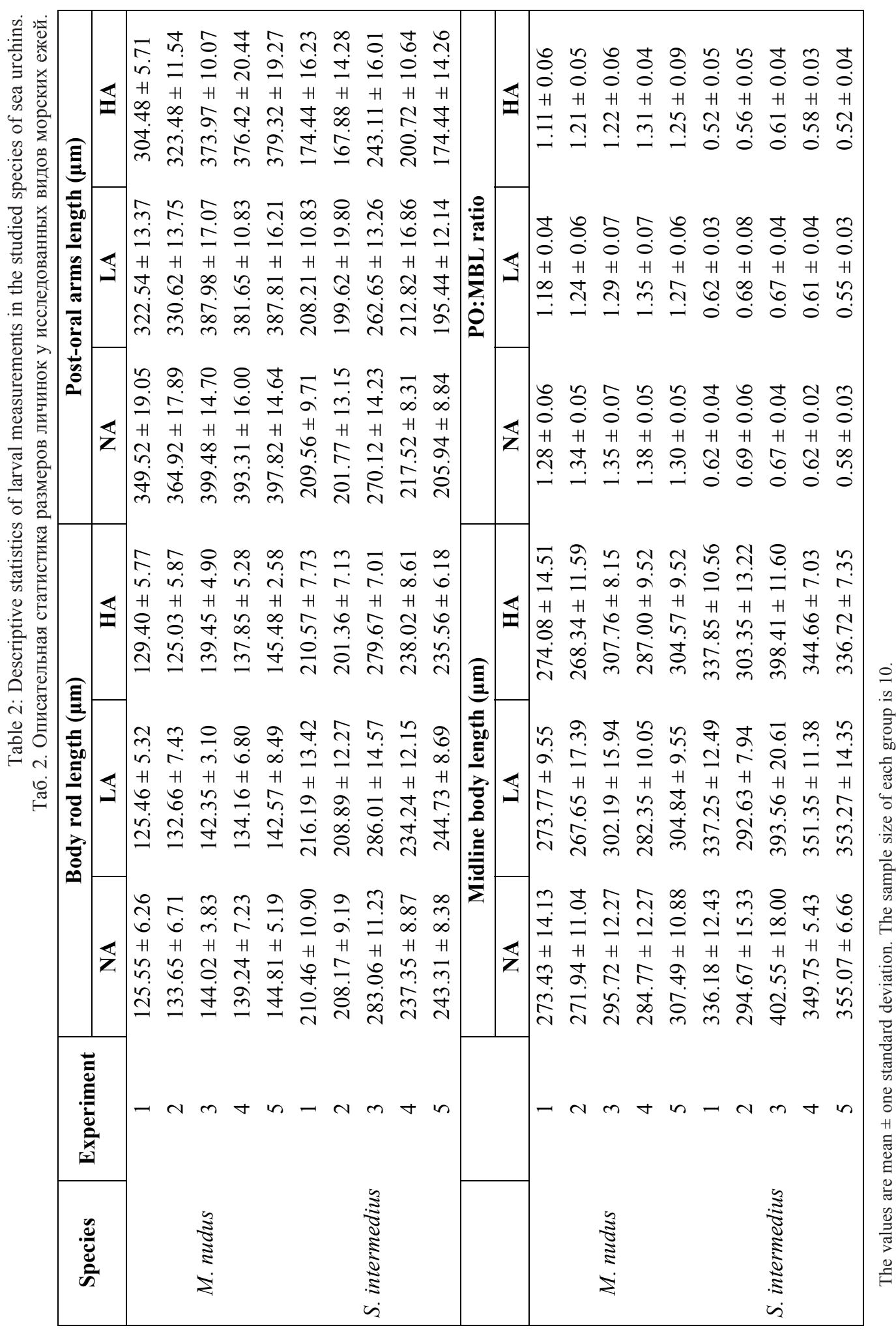




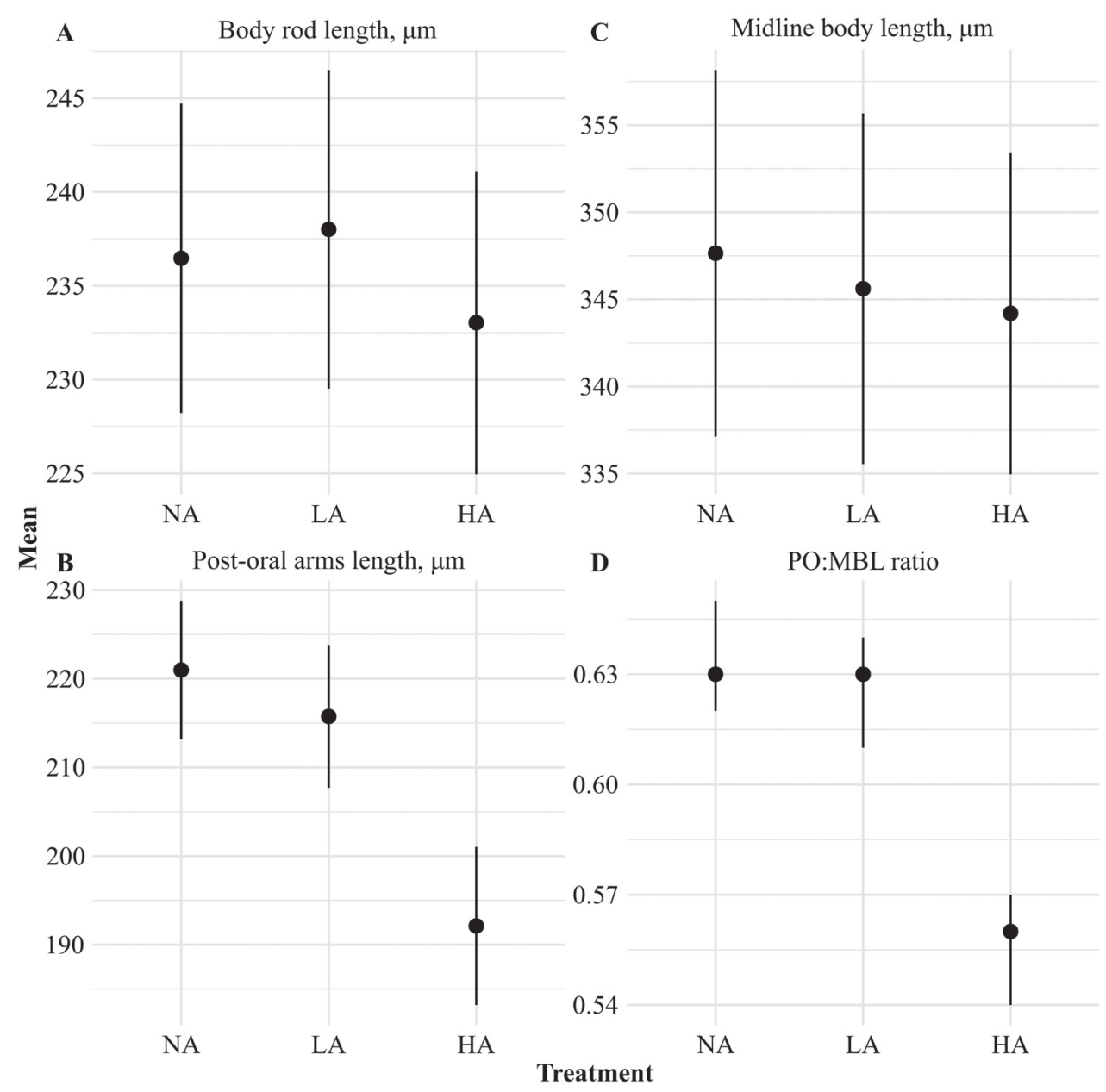

Fig. 4. Strongylocentrotus intermedius. Whisker plots of the pooled datasets for lengths of body rods (A), post-oral arms (B), midline body lengths (C), and PO:MBL ratios in $4 \mathrm{~d}$ old larvae from different experimental treatments. Black dots are means and whiskers around mean represent $95 \%$ confidence interval of the mean.

Рис. 4. Strongylocentrotus intermedius. Средние значения (точка) и 95\% доверительные интервалы («усы») данных по длине скелетных игл (А), посторальных рук (В), средней линии тела (C) и отношения длины посторальных рук к длине средней линии тела (D) четырехдневных личинок из разных экспериментальных групп.

ference in mean length of post-oral arms between experimental treatments was also observed (nested ANOVA: $F(2,143)=62.69, p<$ $\left.2 \times 10^{-16}\right)$. Tukey's HSD test showed statistically significant difference in the mean length of post-oral arms between the larvae from HA experimental treatment and those from NA and LA $\left(p<1 \times 10^{-4}\right)$ experimental treatments (Fig.
4B; Table 2). No statistically significant difference in post-oral arms length between NA and LA treatments was observed $\left(p=1.4 \times 10^{-1}\right)$. The absolute lengths of post-oral arms in the larvae from HA treatment were approximately 13 and $11 \%$ shorter than those from NA and LA treatments, respectively, while the difference in post-oral arms length in the larvae from LA and 


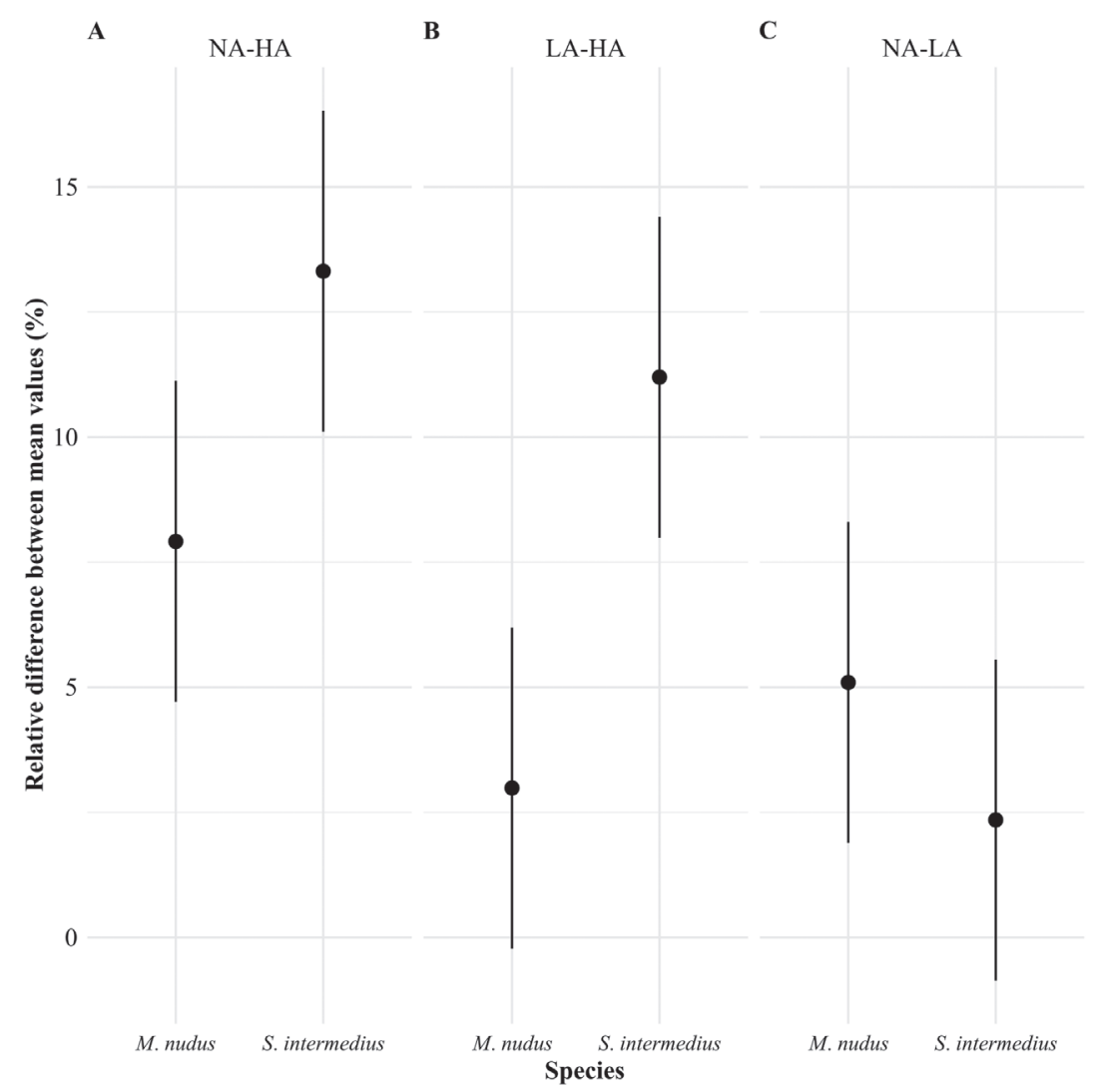

Fig. 5. Whisker plots of the pooled datasets for relative mean difference in post-oral arm lengths for NA-HA (A), LA-HA (B), and NA-LA (C) treatments. Black dots are means and whiskers around means represent $95 \%$ confidence interval of the mean.

Рис. 5. Средние значения (точка) и 95\% доверительные интервалы («усы») для относительной разницы в длине посторальных рук у личинок между экспериментальными группами NA и HA (A), LA и НA (B), и NA и LA (C).

NA treatments was approximately $2 \%$ (Fig. $4 \mathrm{C}$; Table 2).

No statistically significant difference in midline body length was found in $S$. intermedius $($ nested ANOVA: $F(2,143)=0.91, p=4.1 \times$ $\left.10^{-1}\right)$. The difference in absolute midline body lengths between treatments did not exceed $1 \%$ (Fig. 4D; Table 2). However, statistical analysis showed that, as in $M . n u d u s$, the difference in post-oral arms to midline body length ratio is statistically significant (nested ANOVA: $F(2$, $\left.143)=44.92, p=7.28 \times 10^{-16}\right)$. Tukey's HSD test showed that the difference between HA and two other treatments was statistically significant $\left(p<1 \times 10^{-4}\right)$, while the difference between
LA and NA treatments was statistically nonsignificant $\left(p=4.5 \times 10^{-1}\right)$.

\section{Relative change in post-oral arms} length

Finally, we did between species pairwise comparisons for absolute and relative mean difference in post-oral arms length for each experimental treatment (Fig. 5). These results indicated that the absolute difference in postoral arms length between NA and HA treatments was close in both species (29.48 and $28.86 \mu \mathrm{m}$ in $M$. nudus and $S$. intermedius, respectively) and was found to be statistically non-significant $\left(p=9.3 \times 10^{-1}\right)$. However, the 
relative difference in post-oral arms length in $M$. $n u d u s$ was approximately 1.7 times smaller than that in S. intermedius (Fig. 5A) and this difference was statistically significant $(p=2.2 \times$ $10^{-3}$ ). Similarly, the absolute difference in postoral arms length between LA and HA treatments was found to be statistically non-significant $(p=$ $\left.1.7 \times 10^{-1}\right)$, while the relative difference was statistically significant at the level of $p=1 \times 10^{-3}$ (Fig. 5B). On the contrary, the absolute difference in post-oral arms length for NA and LA treatments (18.89 and $5.13 \mu \mathrm{m}$ in M.nudus and $S$. intermedius, respectively) was found to be statistically significant $\left(p=4 \times 10^{-2}\right)$, while the relative difference for the treatments (Fig. 5C) was statistically non-significant $\left(p=2.2 \times 10^{-1}\right)$.

\section{Discussion}

We observed a significant effect of algae concentration on the growth of pre-feeding larvae of both $M$. nudus and S. intermedius. These results agree with previous findings in other echinoids (Soars et al., 2009; McAlister, Miner, 2018). Although the length of the post-oral arms was found to be highly affected by algae concentration, the effect of the algae on length of body rods as well as the midline body length was less pronounced both in $M$. nudus and S. intermedius. We suggest that despite the difference in mean lengths of body rods between HA and LA treatments in S. intermedius was found to be statistically significant, this difference is small and is unlikely to have any important biological meaning. Studies on the effect of algae concentration on development of early larvae in the other species of echinoids revealed a comparable effect of algae on body rods length (Sewell et al., 2004; Miner, 2005; Miner, 2007; Byrne et al., 2008a; Soars et al., 2009). The authors of these studies also suggested that the effect of the algae concentration on body rods length in larvae of echinoids do not have an important biological significance. Nevertheless, future studies on how algae effect on growth of body rods in pre-feeding larvae affects larvae fitness later in development are required to validate this assumption.
Interestingly, our results indicate that relationship between egg size and initial larvae size in four-armed plutei of M. nudus and S. intermedius differs from those reported by McEdward (1986) for four-armed plutei of S. droebachiensis, S. franciscanus, and S. purpuratus. According to McEdward (1986), initial larval size, expressed as midline body length, is positively correlated with egg size, i.e. the bigger the eggs, the larger the early larvae. In our study we found that midline body length in four-armed plutei of M. nudus was approximately 1.2 times shorter than that in $S$. intermedius, while eggs in $M$. nudus were bigger (Table 1).

Larvae of M. nudus and S. intermedius responded differently to various concentrations of algae in their environments. In M. nudus there was a concentration dependent gradual change in post-oral arms length, and, hence, in the PO:MBL ratio, i.e. the higher the algae concentration, the shorter post-oral arms and lower PO:MBL ratio in the larvae. On the contrary, in $S$. intermedius this gradual change in larvae morphometrics was less evident and only two extremes were observed, except for experiment 5. This interspecific difference in response to LA treatment can be explained by difference in maternal investment and how $M$. nudus and $S$. intermedius allocate the resources, stored in eggs, to initial growth of their larvae. We suggest, that since $S$. intermedius has smaller eggs that, presumably, accumulate less resources for larval development, this species is more dependent on exogenous food and should invest more resources into early development of food-gathering structures when food is scarce. Besides, our data indicate that in all experimental treatments $4 \mathrm{~d}$ old larvae of $M$. nudus had longer post-oral arms and shorter bodies as compared to $4 \mathrm{~d}$ old larvae of $S$. intermedius and this indicates that $M$. nudus and S. intermedius differentially invest maternal resources into growth of bodies and arms in pre-feeding larvae (see data on PO:MBL ratio in Table 2).

Despite our results generally agreeing with the literature data on other echinoids, direct comparisons with literature should be done with caution. First, many studies on phenotypic plas- 
ticity in sea urchins and sand dollars deals with feeding larvae (Boidron-Métairon, 1988; McAlister, 2007; Sewell et al., 2004; Byrne et al., 2008a; Soars et al., 2009), yet the plasticity is more evident and detectable in early larvae (Hart, Strathmann, 1994; McAlister, Miner, 2018). Hart and Strathmann (1994) found that in Dendraster excentricus, 3 d old larvae, fed small food ration had longer ciliated bands than those, fed high food ration, while for older larvae ( $>7 \mathrm{~d}$ old) the opposite was true. Second, algae concentrations significantly differ between studies and this difference probably affects how phenotypic plasticity is expressed. For example, Soars et al. (2009) in their study of phenotypic plasticity in Heliocidaris tuberculata used concentration of algae for high and low food treatments two times as high as compared to the study of another echinometrid, Evechinus chloroticus, by Sewell et al. (2004). The authors concluded that both species are phenotypically plastic. However, these studies provide opposite results for plasticity of the larvae from low food treatment (see Table 5 in Soars et al., 2009). Because of such a large difference in algae concentration between the studies, it is unclear whether this difference in response to low algae concentration is due to some interspecific difference between $H$. tuberculata and $E$. chloroticus or it is due to difference in the experimental designs. Nevertheless, taking into account all available data (for summary, see Soars et al., 2009; McAlister, Miner, 2018), one can conclude that post-oral arms growth in early larvae of sea urchins depends on algae concentration in the environment and is inversely related to it. This assumption is supported by the study of Adams et al. (2011), who showed that algae induced dopamine signalling through a dopamine type- $\mathrm{D}_{2}$ receptor (DRD2) influences the rate of arms growth in pre-feeding larvae of $S$. purpuratus. The authors found that pharmacological activation of the DRD2 function with quinpirole mimics the phenotype of the larvae, developed in the presence of large amount of food; the quinpirole action was shown to be dose dependent: the higher the concentration of quinpirole, the shorter the post-oral arms. Ad- ams et al. (2011) suggested that when algae are detected by the plutei, a mechanism that reduces the size of feeding structures is initiated and the plutei "adjust" growth rate of post-oral arms to the actual environmental conditions.

Our results support the assumption that the degree of phenotypic plasticity in the larvae, developing from smaller eggs, is higher than in the larvae, developing from bigger eggs (Reizel, Heyland 2007). We found that in pre-feeding larvae of $M$. nudus and S. intermedius, the species, inhabiting the same geographic region and having approximately 2 -fold difference in egg volumes (Table 1), the difference in absolute length of post-oral arms between no algae and high algae conditions was statistically nonsignificant (Table 2), while the opposite was true for the relative difference in post-oral arms length. When comparing interspecific difference in relative change of PO:MBL ratios between two extremes (NA vs HA treatments), this change was approximately 1.5 -times higher in $S$. intermedius as compared to M. nudus. We believe that these results indicate that pre-feeding larvae of $M$. nudus are less phenotypically plastic that the larvae of $S$. intermedius.

Similar results were reported by Reizel \& Heyland (2007) for 3 and 5 d old larvae of Clypeaster subdepressus, Leodia sexiesperforata, and Mellita tenuis. However, McAlister (2007) in his study of two Strongylocentrotus species found that larvae of $S$. franciscanus, the species with mean egg diameter of approximately $123-125 \mu \mathrm{m}$, are more plastic in arm growth abilities as compared to their counterparts of $S$. purpuratus, the species with mean egg diameter of $82-85 \mu \mathrm{m}$. However, these data cannot be compared with our results directly case in these studies (McAlister, 2007; Reizel, Heyland, 2007) the authors dealt with feeding larvae. Moreover, McAlister (2007) used summed length of post-oral and anterolateral arms as a measure of plasticity and did not report changes in the length of post-oral or anterolateral arms separately.

Based on our results and data from literature (McAlister, 2007; Soars et al., 2009; Adams et al., 2011; McAlister, Miner, 2018), we suggest 
that the length of post-oral arms in pre-feeding larvae of sea urchins is a compromise between the maternal investment into offspring (Byrne $e t$ al., 2008a; Miner, 2007), the genetic program (Carrier et al., 2015; Israel et al., 2016) which determines larval development, the energetic costs of this program (Byrne et al., 2008a; Rendleman et al., 2018), and the actual conditions of the environment where this program is implemented. As a result, depending on the environmental conditions, the genetic program is "corrected" and this "correction" appears as phenotypic plasticity in the rate of post-oral arms growth.

\section{Acknowledgements}

Special thanks to SCUBA divers of the National Scientific Center of Marine Biology for collecting adult sea urchins. The algae, Chaetoceros muelleri, were obtained from Bioresource Center "Marine biobank" (National Scientific Center of Marine Biology FEB RAS, Vladivostok, Russia). The authors are grateful to Drs. Nina Aizdaitcher and Zhanna Markina for their help with algae cultures. All microscopic work has been done at the Far Eastern Center of Electron Microscopy (National Scientific Center of Marine Biology FEB RAS, Vladivostok, Russia). The authors are grateful to Denis Fomin and Kirill Shefer for their help in microscopic studies of larvae. Special thanks to three anonymous reviewers for their suggestions that have substantially improved the manuscript.

\section{References}

Adams D., Sewell M., Angerer R., Angerer L. 2011. Rapid adaptation to food availability by a dopamine-mediated morphogenetic response // Nat. Commun. Vol.2. P.592.

Allen J., Pernet B. 2007. Intermediate modes of larval development: Bridging the gap between planktotrophy and lecithotrophy // Evol. Dev. Vol.9. P.643-653.

Bertram D., Strathmann R. 1998. Effects of maternal and larval nutrition on growth and form of planktotrophic larvae // Ecology. Vol.79. P.315-327.

Boidron-Métairon I. 1988. Morphological plasticity in laboratory reared echinoplutei of Dendraster excentricus (Escholtz) and Lytechinus variegatus (Lamarck) in response to food conditions // J. Exp. Mar. Biol. Ecol. Vol.119. P.31-41.
Byrne M., Sewell M., Prowse T. 2008a. Nutritional ecology of sea urchin larvae: Influence of endogenous and exogenous nutrition on echinopluteal growth and phenotypic plasticity in Tripneustes gratilla // Funct. Ecol. Vol.22. P.643-648.

Byrne M., Prowse T., Sewell M., Dworjanyn S., Williamson J., Vaïtilingon D. 2008b. Maternal provisioning for larvae and larval provisioning for juveniles in the toxopneustid sea urchin Tripneustes gratilla // Mar. Biol. Vol.155. P.473-482.

Carrier T., King B., Coffman J. 2015. Gene expression changes associated with the developmental plasticity of sea urchin larvae in response to food availability // Biol. Bull. Vol.228. P.171-180.

Eckert G. 1998. Larval development, growth and morphology of the sea urchin Diadema antillarum // Bull. Mar. Sci. Vol.63. P.443-451.

George S. 1999. Egg quality, larval growth and phenotypic plasticity in a forcipulate seastar // J. Exp. Mar. Biol. Ecol. Vol.237. P.203-224.

Hart M., Strathmann R. 1994. Functional consequences of phenotypic plasticity in echinoid larvae // Biol. Bull. Vol.186. P.291-299.

Herrera J., McWeeney S., McEdward L. 1996. Diversity of energetic strategies among echinoid larvae and the transition from feeding to nonfeeding development // Oceanol. Acta. Vol.19. P.313-321.

Hothorn T., Bretz F., Westfall P. 2008. Simultaneous inference in general parametric models // Biom. J. Vol.50. P.346-363.

Israel J., Martik M., Byrne M., Raff E., Raff R., McClay D., Wray G. 2016. Comparative developmental transcriptomics reveals rewiring of a highly conserved gene regulatory network during a major life history switch in the sea urchin genus Heliocidaris // PLoS Biol. Vol.14. P. e1002391.

Kashenko S.D. 2010. [The rearing of benthic marine invertebrates under laboratory conditions (Practical recommendations)]. Vladivostok: Dalnauka. 92 p. [in Russian]

Kasyanov V.L. 2001. Reproductive strategy of marine bivalves and echinoderms. Enfield, NH: Science Publishers. 229 p.

Lenth R. 2018. Emmeans: Estimated marginal means, aka least-squares means // R package version 1.2.3. URL: https://CRAN.R-project.org/package=emmeans

McAlister J. 2007. Egg size and the evolution of phenotypic plasticity in larvae of the echinoid genus Strongylocentrotus // J. Exp. Mar. Biol. Ecol. Vol.352. P.306316.

McAlister J. 2008. Evolutionary responses to environmental heterogeneity in Central American echinoid larvae: Plastic versus constant phenotypes // Evolution. Vol.62. P.1358-1372.

McAlister J., Miner B. 2018. Phenotypic plasticity of feeding structures in marine invertebrate larvae $/ / \mathrm{T}$. Carrier, A. Reitzel, A. Heyland (eds.). Evolutionary ecology of marine invertebrate larvae. N.Y.: Oxford University Press. P.103-123.

McEdward L. 1984. Morphometric and metabolic analysis of the growth and form of an echinopluteus // J. Exp. Mar. Biol. Ecol. Vol.82. P.259-287. 
McEdward L. 1985. An apparatus for measuring and recording the depth dimension of microscopic organisms // Trans. Am. Microsc. Soc. Vol.104. P.194-200.

McEdward L. 1986. Comparative morphometrics of echinoderm larvae. I. Some relationships between egg size and initial larval form in echinoids // J. Exp. Mar. Biol. Ecol. Vol.96. P.251-265.

Meidel S., Scheibling R., Metaxas A. 1999. Relative importance of parental and larval nutrition on larval development and metamorphosis of the sea urchin Strongylocentrotus droebachiensis // J. Exp. Mar. Biol. Ecol. Vol.240. P.161-178.

Miner B. 2005. Evolution of feeding structure plasticity in marine invertebrate larvae: A possible trade-off between arm length and stomach size // J. Exp. Mar. Biol. Ecol. Vol.315. P.117-125.

Miner B. 2007. Larval feeding structure plasticity during pre-feeding stages of echinoids: Not all species respond to the same cues // J. Exp. Mar. Biol. Ecol. Vol.343. P.158-165.

Miner B., Vonesh J. 2004. Effects of fine grain environmental variability on morphological plasticity // Ecol. Lett. Vol.7. P.794-801.

Padilla-Gaminõ J., Kelly M., Evans T., Hofmann G. 2013. Temperature and $\mathrm{CO}_{2}$ additively regulate physiology, morphology and genomic responses of larval sea urchins, Strongylocentrotus purpuratus // Proc. R. Soc. B. Vol.280. P.20130155.

Podolsky R., McAlister J. 2005. Developmental plasticity in Macrophiothrix brittlestars: Are morphologically convergent larvae also convergently plastic? // Biol. Bull. Vol.209. P.127-138.
R Core Team. 2018. R: A language and environment for statistical computing // R Foundation for Statistical Computing. Vienna, Austria. URL: https:/www.Rproject.org

Reizel A., Heyland A. 2007. Reduction in morphological plasticity in echinoid larvae: Relationship of plasticity with maternal investment and food availability // Evol. Ecol. Res. Vol.9. P.109-121.

Rendleman A., Rodriguez J., Ohanian A., Pace D. 2018. More than morphology: Differences in food ration drive physiological plasticity in echinoid larvae // J. Exp. Mar. Biol. Ecol. Vol.501. P.1-15.

Schindelin J., Arganda-Carreras I., Frise E., Kaynig V., Longair M., Pietzsch T., Preibisch S., Rueden C., Saalfeld S., Schmid B., Tinevez J.-Y., White J.D., Hartenstein V., Eliceiri K., Tomancak P., Cardona A. 2012. Fiji: An open-source platform for biologicalimage analysis // Nat. Methods. Vol.9. P.676-682.

Schneider C., Rasband W., Eliceiri K. 2012. NIH image to ImageJ: 25 years of image analysis. Nat. Methods. Vol.9. P.671-675.

Sewell M., Cameron M., McArdle B. 2004. Developmental plasticity in larval development in the echinometrid sea urchin Evechinus chloroticus with varying food ration // J. Exp. Mar. Biol. Ecol. Vol.309. P.219-237.

Soars N., Prowse T., Byrne M. 2009. Overview of phenotypic plasticity in echinoid larvae, 'Echinopluteus transversus' type vs. typical echinoplutei// Mar. Ecol. Prog. Ser. Vol.383. P.113-125.

Responsible editor E.N. Temereva 